\title{
Cross-border exchange of electricity between Poland and the neighboring countries
}

ABSTRACT: Ensuring the security of power generation systems is a pillar of the proper functioning of each state. Energy security is fundamental to ensure both economic growth and social welfare. As energy storage has not developed in an efficient extent, covering the current and prospective power demand is a major challenge for transmission system operators. Moreover, the activities that are to be taken should be technically and economically justified and need to meet the requirements of environmental protection. Cooperation between neighboring countries in the field of electricity exchange is among the activities undertaken to ensure the safety of the power generation systems. The integration of electricity markets is one of the key challenges of the European Union's energy policy. The European Commission issued a directive on interconnection, according to which the capacity of interconnections should total $10 \%$ of installed capacity until 2020 (and 15\% until 2030) in each Member State. The main objective of this study is to assess the changes in electricity imports and exports in 2003-2018 and to investigate the current level of cross-border exchanges between Poland and the neighboring countries. This paper also answers the question of whether Poland will fulfil the obligations set by the European Commission. In addition, the paper presents the risks and the challenges related to fulfilling the mentioned commitments. The results of the study indicate that the development and modernization of network infrastructure in the field of cross-border exchange are

$\triangle$ Corresponding Author: Aleksandra Komorowska; e-mail: komorowska@min-pan.krakow.pl

1 Mineral and Energy Economy Research Institute of the Polish Academy of Sciences, Kraków, Poland; ORCID iD: 0000-0002-9604-1071; e-mail: komorowska@min-pan.krakow.pl

2019. The Author(s). This is an open-access article distributed under the terms of the Creative Commons Attribution-ShareAlike International License (CC BY-SA 4.0, http://creativecommons.org/licenses/by-sa/4.0/), which permits use, distribution, and reproduction in any medium, provided that the Article is properly cited. 
necessary because, in the context of the forecasted increase in electricity demand, Polish generation units will not be able to meet the demand.

KEYWORDS: electricity interconnection, cross-border exchange, electricity import, electricity export

\section{Introduction}

Economic development, growing energy demand, increase in the share of renewable energy sources and occurring climate changes lead to the transformation of the energy sector in the world (Giurco et al. 2011; Guo et al. 2019; Sovacool et al. 2019). The electricity demand has been increasing and the structure of its production has been changing in the last years (Ediger 2019; Sikder et al. 2019). Coal-fired power plants that do not meet environmental requirements are being decommissioned and new gas and wind power plants are being connected to the system. The phenomenon is also observed in Poland (Gawlik et al. 2015; Kaszyński 2016).

The changes in the structure of electricity generation in Poland in 2003-2018 are presented in Figure 1. Although the production in hard coal-fired power plants has been approximately $80 \mathrm{TWh} /$ year since 2014, the their share in total electricity production has been increasingly decreasing in the entire period under analysis. On the other hand, the share of gas-fired power plants and power plants based on renewable energy sources has been growing. These changes stem from (i) technological development which results in less expensive costs of electricity

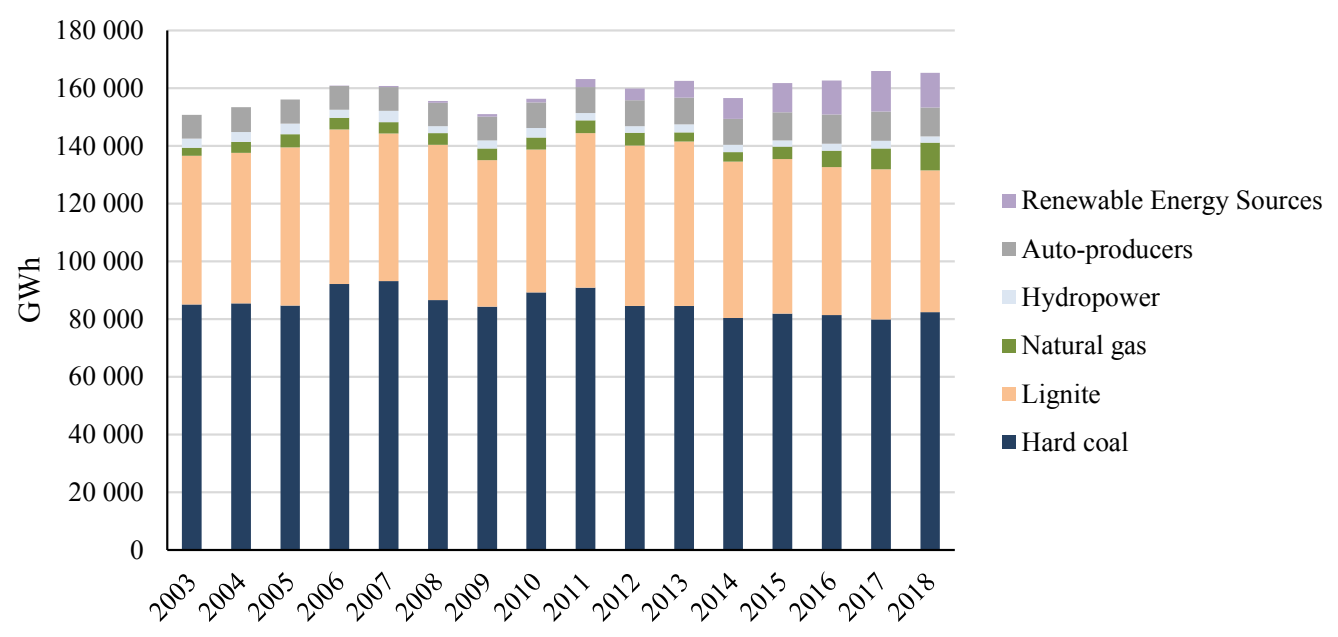

Fig. 1. The structure of electricity generation in Poland in 2003-2018 [GWh]

Source: own analysis based on (PSE 2004-2019)

Rys. 1. Struktura produkcji energii elektrycznej w Polsce w latach 2003-2018 [GWh] 
production in these units than in previous years, and (ii) support mechanisms that are applied to renewable energy sources (e.g. green certificates, auctions).

The introduction of European restrictions regarding emissions (Directive 2010/75/EU, Decision EC 2016/902) into the provisions of Polish law affects the need to adapt national generation units to new emission standards or cease their operation. Table 1 summarizes the cumulative quantities of decommissioning of public power plants until 2035, published by the Polish Transmission System Operator - the Polish Power Grid Company (Polskie Sieci Elektroenergetyczne, PSE SA). The modernization scenario assumes undertaking investments activities to refurbish units that do not meet emission standards, while the withdrawal scenario assumes the acceleration of the decommissioning of these units. Regardless of market conditions favoring modernization investments, the decommissioning of generating units is inevitable. This stems from the fact that most of the coal-fired power plants are over 30 years old (ARE 2018). The mentioned forecast also assumes an increase in capacity demand to $35.2 \mathrm{GW}$ in the winter peak and to $32.7 \mathrm{GW}$ in the summer peak in 2035 (PSE 2016) (the maximum capacity demand totaled $26.3 \mathrm{GW}$ in 2018). Overall, and bearing in mind the current direction of the energy policy in the European Union (EU) (Directive 2009/28/EC, Directive 2018/2001, COM(2018)773), one should expect further decarbonization of the Polish power generation sector.

TABLE 1. The cumulative quantities of decommissioning of public power plants in specific years in the period 2020-2035 [MW]

TABELA 1. Skumulowane wolumeny mocy odstawień jednostek wytwórczych w wybranych latach w okresie 2020-2035 [MW]

\begin{tabular}{|c|c|c|c|c|c|}
\hline \multicolumn{2}{|c|}{ Year } & 2020 & 2025 & 2030 & 2035 \\
\hline Modernization scenario & MW & 2,985 & 3,410 & 5,668 & 14,675 \\
\hline Withdrawal scenario & MW & 4,960 & 9,175 & 16,568 & 20,262 \\
\hline
\end{tabular}

Source: own analysis based on (PSE 2016).

The electricity demand has exceeded electricity production in Polish power generation since 2014 (Fig. 2). This effect is noticed despite the increase in the installed capacity in the power system. The greater dynamics of the electricity demand than the electricity generation in the national power system makes it necessary to import electricity from power plants located in neighboring countries. In order to ensure the security of the electricity supply in the years ahead, it is necessary to carry out investments involving the build and refurbishment of new generating units and cross-border connections.

Changes in the Polish power generation system result in the need to carry out studies on the possibilities of cross-border exchange to investigate the potential for purchasing electricity from neighboring countries. In addition, the European Commission issued a directive on interconnection, according to which the capacity of interconnections should total $10 \%$ of installed capacity until 2020 (and 15\% until 2030) in each Member State (COM(2015)82). So, there is 


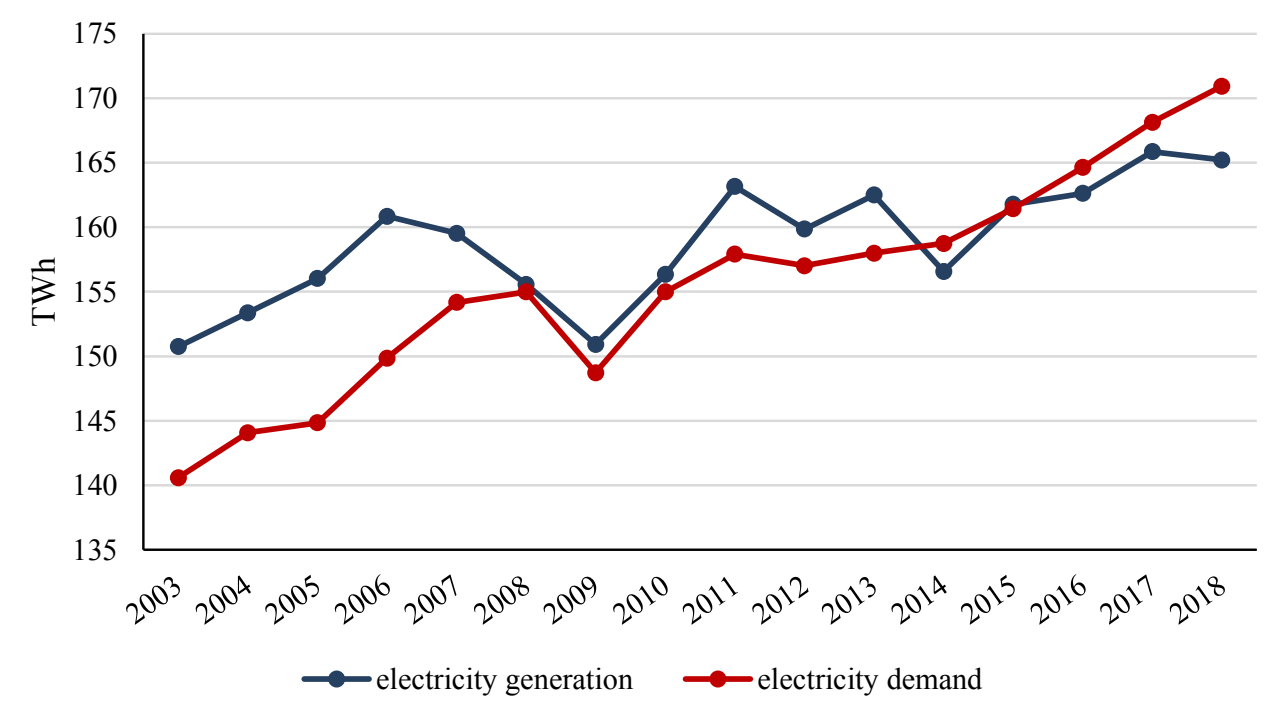

Fig. 2. Electricity generation and electricity demand in 2003-2018 [TWh]

Source: own analysis based on (PSE 2004-2019)

Rys. 2. Produkcja i zapotrzebowanie na energię elektryczną w latach 2003-2018 [TWh]

also a need to assess the degree of fulfilment of EU obligations. To the best of our knowledge, there is no current analysis related to the fulfilment by Poland of the European Commission's target of the capacity of interconnection. With regard of abovementioned conditions, the purpose of this paper is (i) to analyze the current capacity of interconnection and (ii) to assess the degree of fulfilment of the obligation imposed by the European Commission. The paper also analyses electricity imports and exports in 2003-2018.

The remaining of this paper is organized as follows. Section 1 describes the results of a literature review in this research field. The targets of electricity interconnections set by the European Commission are presented in Section 2, and this is followed by the results of the analysis of the current status of cross-border exchange in Poland. Section 3 draws conclusions based on findings.

\section{State of the Art}

Cross-border transmission lines of Polish power generation system are widely discussed in the domestic literature. The possibilities of increasing the cross-border transmission capacity were objective of the study in (Korab 2011). The author analyzed numerous scenarios to increase the potential for cross-border exchange between Poland and the reminder of the Union for 
the Coordination of Transmission of Electricity (UCTE) system. (Korab and Owczarek 2012) studied the impact of phase-shifting transformer on phase angle control. (Kocot et al. 2014) considered the design of the phase-shifting transformer and proposed parameters that may improve their operation. They also analyzed aspects of these elements with the cross-border transmission lines. (Przygrodzki et al. 2018) carried out an analysis of marker effects of connected power generation systems and concludes that market equilibrium allows for the optimal use of electricity produced in a different area. (Dołęga 2018) indicated that the main challenges of National Power System are to expand and refurbish the 400 and $220 \mathrm{kV}$ transmission network and $110 \mathrm{kV}$ distribution network. He pointed out that in the context of growing electricity demand and expanding renewable energy sources, the current network infrastructure is insufficient.

The condition of electricity transmission infrastructure in Europe was analyzed in (Motowidlak 2006). The results indicated that the main challenge in building the European market is the poor condition and congestions in transmission lines. The poor technical condition was also mentioned as a problem in creating of common EU market in (Nowak 2014). (Jankiewicz 2016) presented the consequences of a single electricity market in the European Union and analyzed their effects on the Polish distribution operators. (Rubino and Cuomo 2015) analyzed the impact of Merchant Transmission Investment (MTI) on fulfilment of EU obligation and presented that their contribution would not influence the achievement of the target until 2020.

With regard above, the scientific literature in this field is not ample and there is a lack of study on the current state of cross-border exchange of electricity between Poland and the neighboring countries. The paper contributes in the literature in the following ways: (i) presents the current state of cross-border transmission, (ii) investigates of the degree of fulfilment of EU obligations, and (iii) indicates of the opportunities, risks and challenges associated with the electricity exchange between the neighboring countries.

\section{Current status of cross-border exchange in Poland}

In 2015, the European Commission published a Communication to the European Parliament and the Council regarding the achievement of the $10 \%$ electricity interconnection target making Europe's electricity grid fit for 2020 and the level of $15 \%$ for 2030 (COM(2015)82). The argument for introducing this document is to ensure the security of supply by improving the quality of the European electricity network and creating new interconnections. Achieving a $10 \%$ interconnection level means that each Member State is required to obtain cross-border connections corresponding to at least $10 \%$ of their installed capacity. This mainly applies to the twelve countries mentioned in the communication, in which the level of interconnections is the least developed. Poland was also among them, with a $2 \%$ level in the cross-border exchange in $2014(\operatorname{COM}(2015) 82)$. As installed capacity totaled 38,121 MW in 2014 (PSE 2015), the total cross-border transmission capacity amounted to $762.42 \mathrm{MW}$. 
To enable the implementation of investments in the transmission infrastructure, an instrument was created to identify the necessary projects to improve the European transmission network. Selected projects are on the EU list of projects of common interest (PCIs). One of the finalized projects included in the PCI list is the interconnection between Lithuania and Poland (LitPol) so that the level in the cross-border exchange of our country increased to $4 \%$ in 2015 $(1,617.7 \mathrm{MW})$. The construction of four $400 \mathrm{kV}$ power lines, five high voltage power stations and the modernization of the existing two were carried out as a result of this (PSE 2018a).

The total installed capacity amounted to 45,939 MW in Poland in 2018. Table 2 presents the forecasted installed capacity in the Polish power generation system in the years ahead. The targets of cross-border transmission capacity and the resulting volume of cross-border transmission capacity are also present.

TABLE 2. The forecasted installed capacity in the Polish power generation system and cross-border transmission capacity

TABELA 2. Prognozowany wolumen mocy zainstalowanej w polskim systemie elektroenergetycznym wraz z wolumenem mocy połączeń transgranicznych

\begin{tabular}{|l|c|c|c|}
\hline & Unit & 2020 & 2030 \\
\hline Installed capacity & MW & 42,000 & 57,700 \\
\hline Target of cross-border transmission capacity & $\%$ & 10 & 15 \\
\hline Cross-border transmission capacity & MW & 4,200 & 8,655 \\
\hline
\end{tabular}

Source: own analysis based on (COM(2015)82, ME 2018).

The volume of imported and exported electricity in 2003-2018 is presented in Figure 3. Until 2013, Poland was mainly an exporter of electricity, especially in the west. This stemmed mainly from the lower price of energy produced in Polish power plants than in those of the western neighbors. In the following years, electricity export decreased, which was related to the construction of wind farms in northern Germany. In 2014, Poland became a net importer of electricity for the first time. However, this effect was achieved through the intervention of the Polish transmission operator, not as a result of the rules of the energy market. PSE SA bought 1.5 TWh of electricity in Poland and sent it to Germany in order to offset the effect of circular flows (Jankiewicz 2016).

The Polish power generation system has synchronous connections with (i) the Czech Republic, (ii) Germany and (iii) Slovakia and non-synchronous connections with (iv) Sweden (via the undersea power cable), (v) Lithuania and (vi) Ukraine. The number of existing cross-border connections equals eleven. The list of them with their voltage and bandwidth is summarized in Table 3. The highest volume of cross-border transmission capacity is on the border with Germany, the Czech Republic and Slovakia (synchronous connections).

The cross-border connection with Belarus is excluded due to poor technical condition of the transmission lines and international relations between neighboring countries. The line between Rzeszów and Chmielnicka (Poland-Ukrainian) has not been operated since 1993. Its restart 


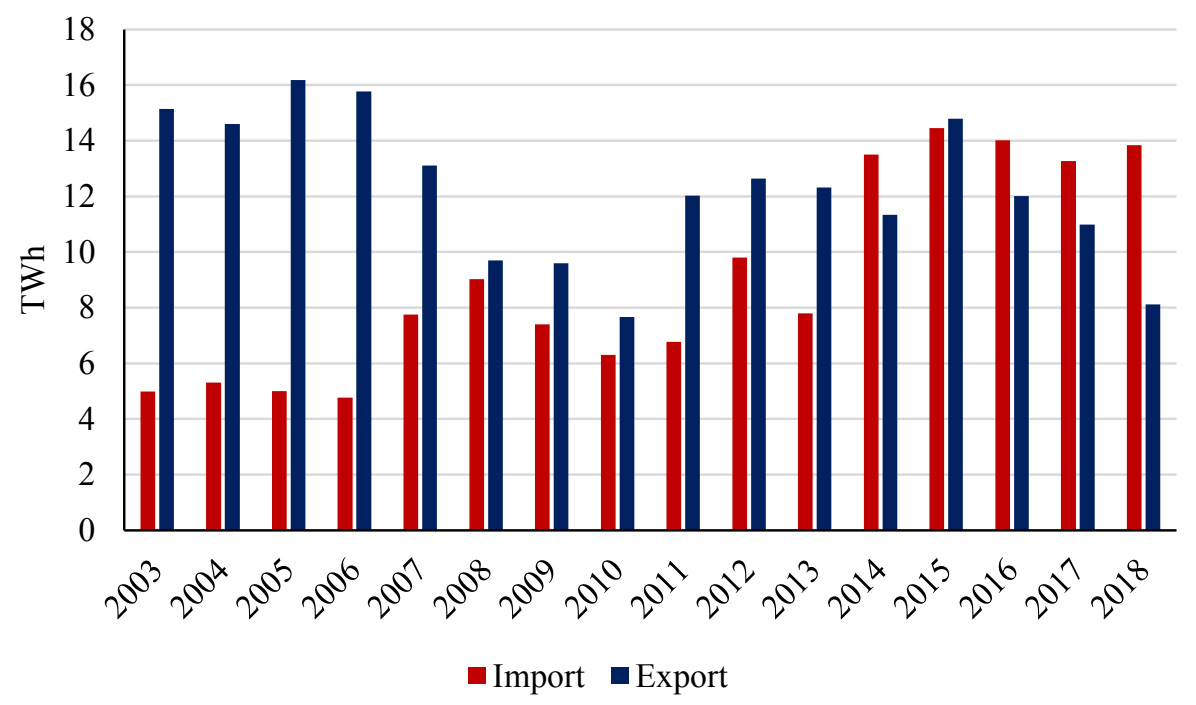

Fig. 3. Import and export of electricity in 2003-2018 [TWh]

Source: own analysis based on (PSE 2004-2019)

Rys. 3. Import i eksport energii elektrycznej w latach 2003-2018 [TWh]

TABLE 3. Cross-border connections between Poland and neighboring countries

TABELA 3. Połączenia transgraniczne pomiędzy Polską a krajami sąsiadującymi

\begin{tabular}{|c|c|c|c|}
\hline Interconnection & Country & Voltage [kV] & Bandwidth $^{1}$ \\
\hline \multicolumn{4}{|c|}{ Synchronous connections } \\
\hline Vierraden-Krajnik & Germany & 400 & $2 \times 408 \mathrm{MVA}$ \\
\hline Hagenverder-Mikułowa & Germany & 400 & $2 \times 1,386 \mathrm{MVA}$ \\
\hline Albrechtice-Dobrzeń & the Czech Republic & 400 & 1,386 MVA \\
\hline Nosowice-Wielopole & the Czech Republic & 400 & 1,386 MVA \\
\hline Liskovec-Kopanina-Bujaków & the Czech Republic & 220 & $2 \times 400 \mathrm{MVA}$ \\
\hline Krosno-Lemesany & Slovakia & 400 & $2 \times 831 \mathrm{MVA}$ \\
\hline \multicolumn{4}{|c|}{ Non-synchronous connections } \\
\hline Ełk-Alytus & Lithuania & 400 & $500 \mathrm{MW}$ \\
\hline Starno-Słupsk & Sweden & 450 & $600 \mathrm{MW}$ \\
\hline Białystok-Roś & Belarus & 220 & excluded \\
\hline Dobrotwór-Zamość & Ukraine & 220 & 415 MVA \\
\hline Rzeszów-Chmielnicka & Ukraine & 750 & excluded \\
\hline
\end{tabular}

Source: own analysis based on (PSE 2018).

1 Among the interconnections mentioned, some of them are characterized by bandwidth expressed in megawatts, and some in mega-volt-amperes. A megawatt is a unit of active power, whereas a mega-volt-ampere is a unit of apparent power. The difference between the mentioned types of power lies in the fact that the active power is the power which is actually consumed or utilized in an AC Circuit. In turn, apparent power is the product of the root mean square (RMS) value of the voltage and current. 
requires the use of frequency converters to introduce the so-called DC inserts in the line path (a similar solution is used in the connection with Lithuania).

Electricity importers in 2018 are presented in Figure 4. Germany had the largest share in these results. The volume of imported electricity totaled 7,340.4 GWh. The other importers were as follows: Sweden, Lithuania, Ukraine and the Czech Republic. The volume of imported electricity is shown in Figure 6. Electricity exporters in 2018 are presented in Figure 5. The Czech

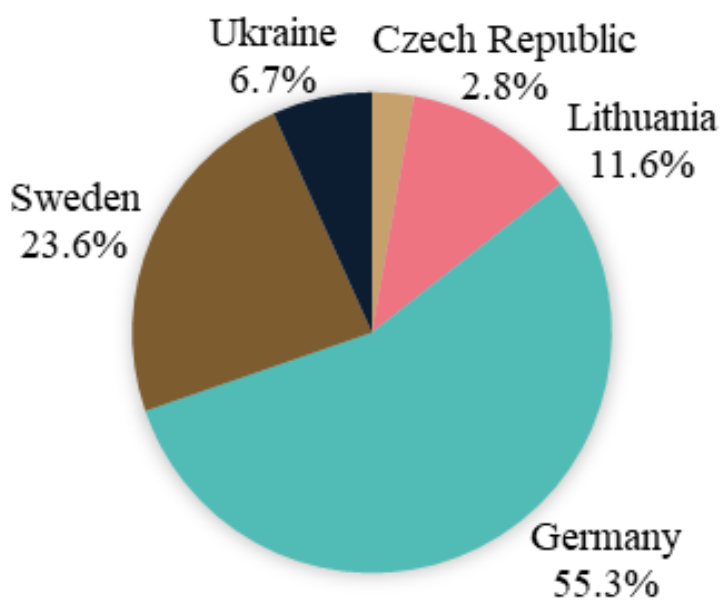

Fig. 4. The share of the neighboring countries in electricity import to Poland Source: own analysis based on (PSE 2019)

Rys. 4. Udział krajów sąsiadujących w imporcie energii elektrycznej do Polski

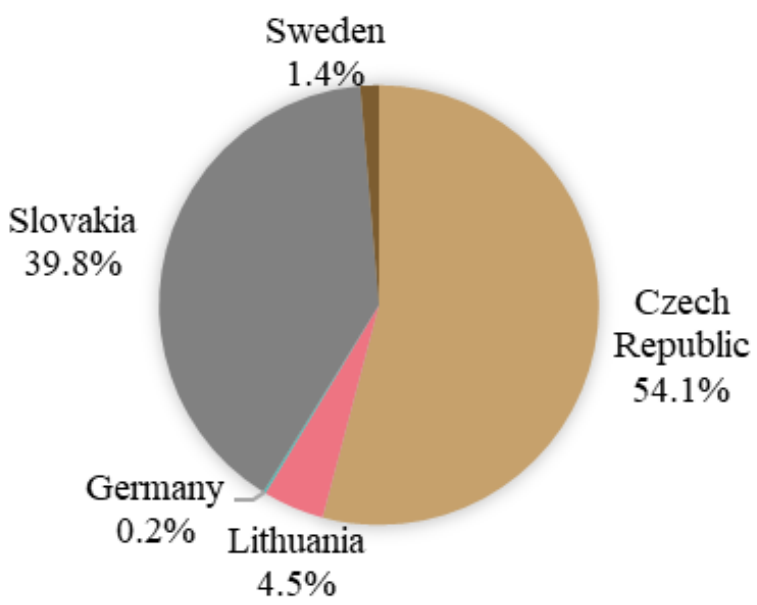

Fig. 5. The share of the neighboring countries in electricity export from Poland Source: own analysis based on (PSE 2019)

Rys. 5. Udział krajów sąsiadujących w eksporcie energii elektrycznej z Polski 
Republic had the largest share in these results. The other exporters were as follows: Slovakia, Lithuania, Sweden and Germany. The volume of exported electricity is also shown in Figure 6. Electricity was not exported to Ukraine and Belarus.

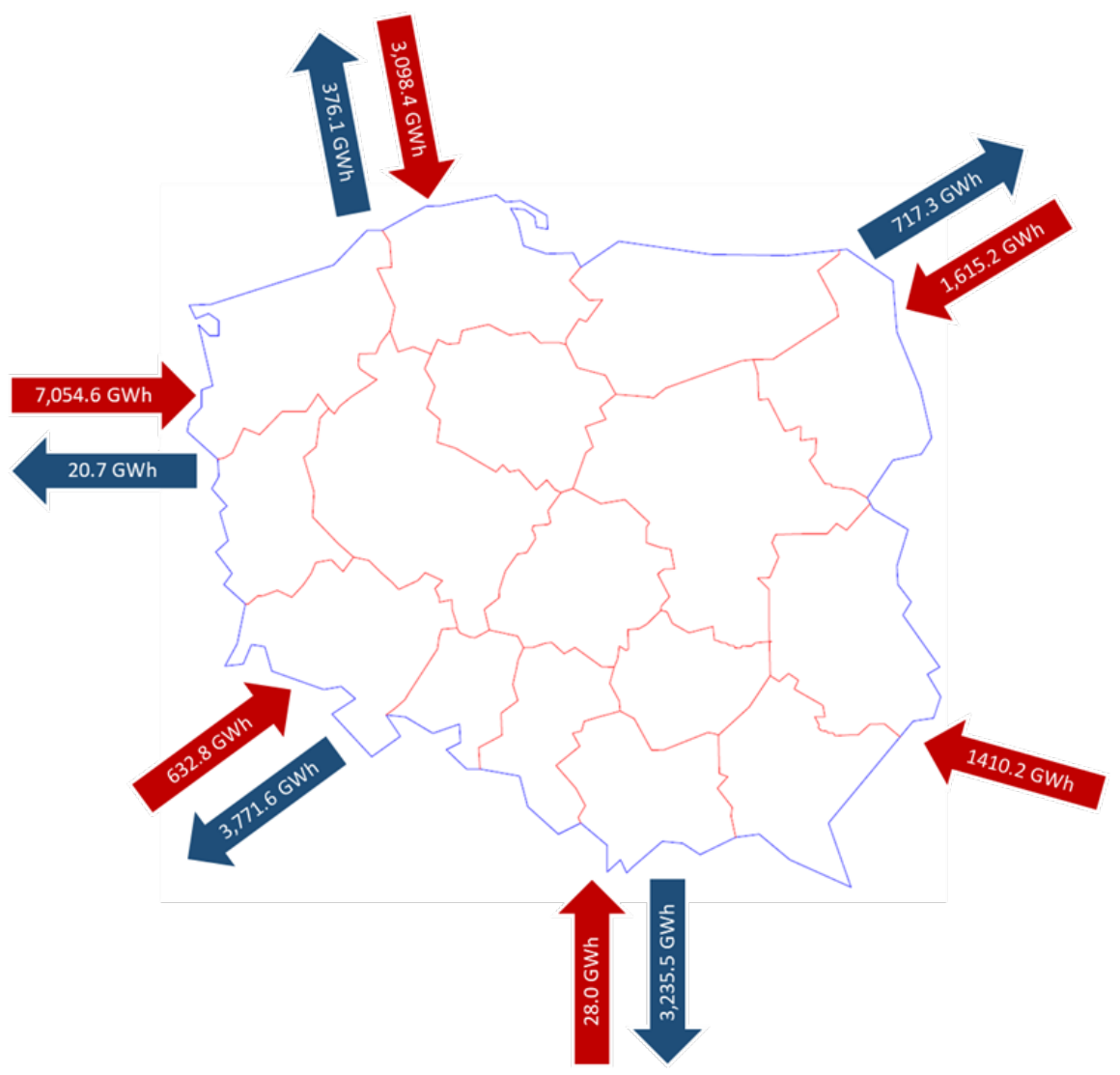

Fig. 6. Cross-border exchange of electricity in 2018 [GWh]

Source: own analysis based on (PSE 2019)

Rys. 6. Wymiana międzysystemowa energii elektrycznej w 2018 roku [GWh]

The $10 \%$ share in the cross-border connections means that Poland should have transmission capacities of at least $4.2 \mathrm{GW}$ until 2020 . The presented data indicates that the total capacity of cross-border connections is already significantly above this value (Table 3 ). It can be noticed that the capacity of the existing cross-border connections is not fully used. Figure 7 presents the offered transfer capacity in 2018. The Total Transfer Capacity (TTC) is defined as the maximum capacity which can be exchanged between neighboring countries. The TTC includes (i) Net Transfer Capacity (NTC) and (ii) Transmission Reliability Margin (TRM). As the TTC was equaled the TRM, the NTC of import equaled 0 in each month of 2018. The maximum of NTC of export amounted to $1.7 \mathrm{GW}$. 


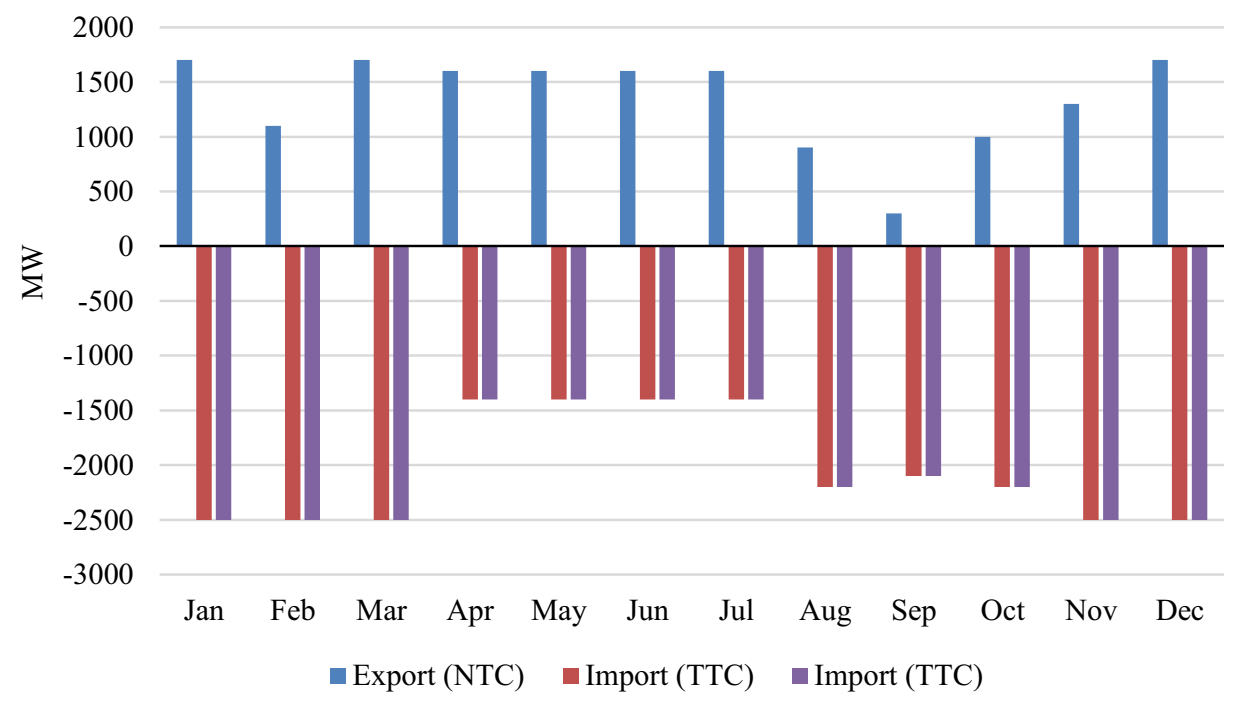

Fig. 7. Transfer capacity in 2018 [MW]

Source: own analysis based on (PSE 2018b)

Rys. 7. Moc transgranicznych zdolności przesyłowych w 2018 roku [MW]

Problems related to network limitations (age, technical condition and extent of network depletion) and power shaping (e.g. the problem of circular flows) are among the reasons for the inability to use the existing potential of the transmission networks. Consequently, in order to improve the actual energy flows, both new cross-border connections should be built and the transmission networks of the national power system should be modernized. This will allow the actual level of Poland's inter-system exchange, whose actual value is much lower than the theoretical level, to be improved. In order to reduce the occurrence of circular flows, one should focus on increasing the installed phase shifters on connections with Germany, the Czech Republic and Slovakia. Phase shifts allow the power flow to be controlled regardless of the place of production and affect the improvement of the possibility of using existing transmission capacities for commercial purposes.

It is estimated that the transmission capacity of cross-border connections will increase in the coming years mainly due to the planned investments at the border with Lithuania (2-3 GW of new connections by 2020) and Germany ( 2 GW of new connections by 2020 and the modernization of the existing ones). Investments between Poland and Ukraine, improving transmission capacities up to $600 \mathrm{MW}$ (import) and $820 \mathrm{MW}$ (exports), are also planned for implementation. In the case of the non-synchronous connection of the Polish transmission system with the Swedish system, no investments are planned to increase its transmission capacity. Forecasts of the total increase in interconnector capacity in electricity import and export are presented in Table 4. On the basis of the presented data, export is expected to increase to 470 and $650 \%$ and import to $221.2 \%$ and $433.3 \%$ (in comparison to 2016 ) by 2020 and 2030 respectively. The expected 
import bandwidth from Germany, the Czech Republic and Slovakia are 2500 and 3000 MW successively up to 2025 and 2030, while export bandwidth is expected at a level of $2000 \mathrm{MW}$. If the planned investments are implemented, it will possible to achieve the actual level of cross-border exchange at the level of $15 \%$ assumed in the Communication of the European Commission.

TABLE 4. Forecast of cross-border transmission capacity [MW]

TABELA 4. Prognozowane wolumeny mocy połączeń transgranicznych [MW]

\begin{tabular}{|c|c|c|c|}
\hline & 2016 & 2020 & 2030 \\
\hline Export bandwidth & $1000 \mathrm{MW}$ & $4700 \mathrm{MW}$ & $6500 \mathrm{MW}$ \\
\hline Import bandwidth & $1320 \mathrm{MW}$ & $2920 \mathrm{MW}$ & $5720 \mathrm{MW}$ \\
\hline
\end{tabular}

Source: own analysis based on (ENTSO-E 2014).

However, it should be noted that increasing the import capacity of the Polish transmission system can bring risks. One of them is the low competitiveness of the electricity produced in Polish coal-fired power plants on the international energy market. The pursued energy policy and the imposition of increasingly stringent emission standards for public power plants result in higher prices in Poland. Electricity produced in power plants located in neighboring countries is less expensive. This is related, inter alia, to the support mechanism for renewable energy used in Germany and the lack of emission fees in countries outside the European Union. In his article, (Jankiewicz 2016) pointed out the potential effects of energy market integration with neighboring countries for the Polish power system. Among the biggest risks, he mentioned a decline in production in domestic generating units, a lack of fund for their modernization and an increase in dependence on foreign producers.

\section{Conclusions}

The main objective of this study was to assess the changes in electricity import and export in the years 2013-2018 and to investigate the current level of Poland's cross-border exchange with its neighboring countries. On the basis of the obtained results, it can be concluded that the volume of electricity imports and exports to the national power system depends on many factors, not only on the size of the domestic demand. The poor technical condition of the transmission line has been pointed out, which affects the volume of the transmitted electricity. The occurrence of circular flows that hinder the trade on the international energy market was highlighted as well. One of the solutions eliminating this phenomenon is the assembly of phase shifts on cross-border connections with Germany, the Czech Republic and Slovakia so that the maintenance of electricity trade is possible (Korab and Owczarek 2012). 
The paper points out the difference between the theoretical bandwidth of existing cross-border connections and actual flows. The theoretical bandwidth is much more than $10 \%$ indicated in the European Union Communication. However, the actual value is much lower. In the coming years, investments in this area are needed to reach the real level of $10 \%$ by 2020 and $15 \%$ by 2030.

The integration of the electricity market in the European Union is primarily the energy safety and the independence of the Union from energy supplies from neighboring countries. However, it should be borne in mind that the development of interconnections in the case of Poland carries a risk. The price of electricity in Poland is higher than in other countries, hence import and dependence on neighboring states should be expected.

In summary, the development and modernization of network infrastructure in the field of cross-border exchange are necessary because, in the context of the forecasted increase in electricity demand, Polish generation units will not be able to meet the demand. The results of studies carried out in other European countries indicate that the greater integration of electricity markets may help (i) achieve European targets and (ii) ensure energy safety (Fuentes 2015; Knudsen et al. 2016; Poudineh and Rubino 2017).

Another one of the solutions to prevent the blackouts are capacity remuneration mechanisms. However, the introduction of the capacity market in Poland will also influence a cross-border exchange. The analysis of this mechanism (Benalcazar and Kamiński 2016; Bhagwat et al. 2017; Hawker et al. 2017; Komorowska and Kamiński 2019; Michalski and Sołtysik 2016) indicates that it will have long-term consequences for domestic or European trade of electricity or capacity. This should be taken into account in the further analyses in this field.

This paper was partially performed within the statutory research program of the Mineral and Energy Economy Research Institute, PAS.

\section{References}

ARE 2018. Energy Statistics. Warsaw. Energy Market Agency (Agencja Rynku Energii, ARE) (in Polish). BENALCAZAR, P. and KAMIŃSKI, J. 2016. Capacity markets and cogeneration facilities: recommendations for Poland. Polityka Energetyczna - Energy Policy Journal Vol. 19, Iss. 3, pp. 61-76.

Bhagwat et al. 2017 - Bhagwat, P.C., Marcheselli, A., Richstein, J.C., Chappin, E.J.L. and De VRIES, L.J. 2017. An analysis of a forward capacity market with long-term contracts. Energy Policy 111 , pp. 255-267.

$\operatorname{COM}(2015) 82$. Communication: Achieving the 10\% electricity interconnection target Making Europe's electricity grid fit for 2020 .

COM(2018)773. Communication: A Clean Planet for all - A European strategic long-term vision for a prosperous, modern, competitive and climate neutral economy.

Decision EC 2016/902. Commission implementing decision (EU) 2016/902 of 30 May 2016 establishing best available techniques (BAT) conclusions, under Directive 2010/75/EU of the European Parliament and of the Council, for common waste water and waste gas treatment/ management systems in the chemical sector. 
Directive (EU) 2018/2001. Directive (EU) 2018/2001 of the European Parliament and of the Council of 11 December 2018 on the promotion of the use of energy from renewable sources.

Directive 2009/28/EC. Directive 2009/28/EC of the European Parliament and of the Council of 23 April 2009 on the promotion of the use of energy from renewable sources and amending and subsequently repealing Directives 2001/77/EC and 2003/30/EC.

Directive 2010/75/EU. Directive 2010/75/EU of the European Parliament and of the Council on industrial emissions (integrated pollution prevention and control).

DoŁĘGA, W. 2018. National grid electrical power infrastructure - threats and challenges. Polityka Energetyczna - Energy Policy Journal Vol. 21, Iss. 2, pp. 89-103.

EDIGER, V.Ş. 2019. An integrated review and analysis of the multi-energy transition from fossil fuels to renewables. Energy Procedia 156, pp. 2-6.

ENTSO-E 2014. Scenario outlook and adequacy forecast 2014-2020. European Network of Transmission System Operators for Electricity (ENTSO-E).

FUENTES, R.S. 2015. Energy security in the European power system towards 2030: technology and regulatory frame for the integration of the German, French and Spanish power systems. Universitat Politècnica de Catalunya.

GaWliK et al. 2015 - Gawlik, L., SzURleJ, A. and Wyrwa, A. 2015. The impact of the long-term EU target for renewables on the structure of electricity production in Poland. Energy 92, pp. 172-178.

Giurco et al. 2011 - Giurco, D., CoHEN, B., LANGHAM, E. and WARNKEN, M. 2011. Backcasting energy futures using industrial ecology. Technological Forecasting and Social Change 78/5, pp. 797-818.

GuO et al. 2019 - GuO, P., Kong, J., GuO, Y. and LIU, X. 2019. Identifying the influencing factors of sustainable energy transitions in China. Journal of Cleaner Production 215, pp. 757-766.

HAWKER et al. 2017 - HAWKER, G., Bell, K. and GILl, S. 2017. Electricity security in the European Union - The conflict between national Capacity Mechanisms and the Single Market. Energy Research \& Social Science 24, pp. 51-58.

JANKIEwicZ, S. 2016. Cross-Border Connections of Polish Power Network and the Value of the Distribution System Operator. Zarzadzanie i Finanse 14, pp. 73-84.

KASZYŃSKI, P. 2016. The concept of the implementation of environmental regulations in the long-run model of the Polish power generation system. Polityka Energetyczna - Energy Policy Journal Vol. 19, Iss. 2, pp. 5-22.

KNUdSEN et al. 2015 - KNUdSEN, J., JACOBSEN, G. and Kielland HAUG, J.J. 2016. Business model for cross-border interconnections in the Mediterranean basin. Oxford Institute for Energy Studies.

Kocot et al. 2014 - Kocot, H., Korab, R., PrzygrodzKi, M. and ŻMUdA, K. 2014. The selection of the main parameters of phase shifting transformers for the western cross-border transmission lines of Polish Power System. Przeglad Elektrotechniczny 90, pp. 124-127.

KomorowsKa, A. and KAMIŃSKI, J. 2019. A review of the 2018 Polish capacity market auctions. Polityka Energetyczna - Energy Policy Journal Vol. 22, Iss. 2, pp. 75-88.

KorAB, R., 2011. Possibilities of increasing the Polish cross-border transmission capacity. Przeglad Elektrotechniczny 87, pp. 87-90.

KORAB, R. and Owczarek, R. 2012. Cross-border power flow control by using phase shifting transformers. Przeglad Elektrotechniczny 88, pp. 299-302.

ME 2018. Conclusions from analyses for the energy sector - Annex 1 to the Polish Energy Policy until 2040 (Project - int. 1.2 - 23.11.2018). Warsaw: Ministry of Energy (ME) (in Polish).

MichalsKi, D. and SoŁTysiK, M. 2016. The Next Step in Development of European Power Market - Capacity Market. Unia Europejska 3, pp. 49-60.

MotowidLAK, T. 2006. Cross-border connections as part of the single European electricity market. Elektroenergetyka 3, pp. 20-60. 
NowAK, B. 2014. Different Approaches, One Target: Towards a Common EU Position on Energy Security. Sprawy międzynarodowe 1, pp. 39-53.

PoudineH, R. and RUBINO, A. 2017. Business model for cross-border interconnections in the Mediterranean basin. Energy Policy 107, pp. 96-108.

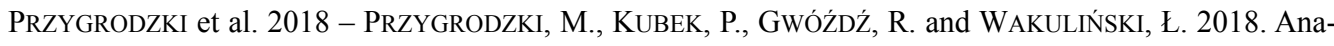
lysis of market effects of connected power systems. Rynek Energii 2, pp. 3-9.

PSE 2004-2019. Summary of quantitative data on the functioning of the National Power System in 2003-2018. Polish Power Grid Company (Polskie Sieci Elektroenergetyczne, PSE).

PSE 2015. Summary of quantitative data on the functioning of the National Power System in 2014. Polish Power Grid Company.

PSE 2016. Development plan for meeting the current and future electricity demand for 2016-2035. Polish Power Grid Company.

PSE 2018a. Power connection between Poland and Lithuanian. Polish Power Grid Company.

PSE 2018b. Transmission capacity offered in 2018. Polish Power Grid Company.

PSE 2019. Summary of quantitative data on the functioning of the National Power System in 2018. Polish Power Grid Company.

Rubino, A. and CuOMO, M. 2015. A regulatory assessment of the Electricity Merchant Transmission Investment in EU. Energy Policy 85, pp. 464-474.

SiKDER et al. 2019 - SiKDER, A., INEKWE, J. and BhATTACHARYA, M. 2019. Economic output in the era of changing energy-mix for G20 countries: New evidence with trade openness and research and development investment. Applied Energy 235, pp. 930-938.

Sovacool et al. 2019 - Sovacool, B.K., Hook, A., MArTiSKainen, M. and BAKER, L. 2019. The whole systems energy injustice of four European low-carbon transitions. Global Environmental Change 58, pp. 101958.

\section{Wymiana międzysystemowa energii elektrycznej pomiędzy Polską a krajami sąsiadującymi}

\section{Streszczenie}

Zapewnienie bezpieczeństwa pracy systemów elektroenergetycznych jest filarem prawidłowego funkcjonowania każdego państwa. Ponieważ obecny rozwój technologii magazynowania energii nie zapewnia jej efektywnego przechowywania, pokrycie bieżącego i perspektywicznego zapotrzebowania odbiorców na energię elektryczną stanowi duże wyzwanie dla operatorów systemów przesyłowych. Zwłaszcza, że podejmowane działania powinny być technicznie i ekonomicznie uzasadnione oraz muszą spełniać wymagania dotyczące ochrony środowiska. Współpraca pomiędzy krajami sąsiadującymi w obszarze wymiany energii elektrycznej należy do działań podejmowanych w celu zapewnienia bezpieczeństwa dostaw energii elektrycznej, a integracja rynków energii elektrycznej jest jednym z kluczowych wyzwań polityki energetycznej Unii Europejskiej. W 2015 roku Komisja Europejska wydała dyrektywę dotyczącą połączeń trans- 
granicznych, zgodnie z którą wolumen mocy tych połączeń powinien osiągnąć $10 \%$ mocy zainstalowanej do 2020 roku (i 15\% do 2030 roku) w każdym państwie członkowskim.

Głównym celem artykułu jest ocena zmian wolumenu importowanej i eksportowanej energii w latach 2003-2018 oraz oszacowanie obecnego poziomu wymiany transgranicznej między Polską a krajami sąsiadującymi. Wyniki zaprezentowane w niniejszym artykule, odpowiadają również na pytanie, czy Polska jest w stanie wypełnić zobowiązania określone przez Komisję Europejską. Ponadto, w artykule zaprezentowane zostały ryzyka oraz wyzwania związane z realizacją wymienionych zobowiązań. Wyniki wskazują, że rozwój oraz modernizacja infrastruktury sieciowej w zakresie wymiany transgranicznej są konieczne, ponieważ w kontekście prognozowanego wzrostu zapotrzebowania na energię elektryczną polskie jednostki wytwórcze nie będą w stanie pokryć go samodzielnie.

SŁOWA KLUCZOWE: połączenia transgraniczne, wymiana międzysystemowa, import energii elektrycznej, eksport energii elektrycznej 
